\title{
SELECTING OPTIMUM METHOD FOR SOWING CANOLA CROP (BRASSICA RAPUSL)
}

\author{
AL-Gezawe, A. A. I *
}

\section{ABSTRACT}

The aim of this research is to study the effect of some manual and mechanical planting methods on canola crop yield. Three manual as well as two mechanical methods of planting canola crop were conducted. Mechanical planting methods were carried out under four different forward speed. Manual and mechanical planting methods were evaluated in terms of field capacity and field efficiency, plant characteristics, crop yield, energy requirements and planting cost. The main results in this study can be summarized in the following points:

*The heihest yield (1580 kg/fed) was obtained by using pneumatic planter with row spacing of $40 \mathrm{~cm}$, while lowest yield (924 kg/fed)was obtained by using manual broadcasting method.

*The heihest value of cost per feddan (300 L.E/fed)was obtained by using manual transplanting method, while the lowest value(14.8L.E./fed)was obtained by using seed-drill.

It is recommended to use the pneumatic planter at a forward speed $4 \mathrm{~km} / \mathrm{h}$ for planting canola crop to maximize crop yield and minimize planting cost.

\section{INTRODUCTION}

anola plant grown primarily for the production of oil . Where tanks
second in the world in terms of vegetable oils after soyabeans.
Grown widely in North America and Canada is one of the first
countries producing canola crop accounting for $63 \%$ of total oil producer.
Also considered crop fifth world in were the world trade after rice, wheat,
corn, and cotton. Oils extracted from plant canola containing $94 \%$ saturated
fatty acids, and only $6 \%$ unsaturated fatty acids and the proportion of oil in
the grain from $45 \%$ to $50 \%$ (Dr. Bahaa EL-Din Makky professor of crop
National Research Center newspaper Al-Aram $13 / 3 / 2010$ ). Reach Egypt,s
oil production does not exceed $10 \%$. Therefore should pay attention to the
planting of canola plant during

* Researcher of Agric. Res. I nst., Agric. Res. Center, Dokki, Egypt. 
the winter season where is the economic gain because it is high productivity without being influenced by the situation of the soil where graciously in most types of land. The twenty most important vegetables in the world planting in total area of about one million hectares, with an annual production of about ten million metric. El-shal (1987) concluded that the pneumatic planter is too effective for all seeds and grains of different sizes and shapes under special suction pressure and feed plate speed to produce high uniformity of seeds distribution and high filling percentage. As well as, Moustafa (1993) mentioned that the highest number of vegetative branches and the highest yield were obtained under pneumatic planter. Mechanical planting (pneumatic planter and seed drill )saved about 67.6 and 31.6\%, respectively of seeds per feddan compared by manual planting. He also added that the mechanical planting treatment produced heavy grains. Abdou (1995) investigated different methods of planting to recommend the most of profitable system, he concluded that using of seed-drill gave the highest sound seedling compared with row planter.Imbabi (1996) indicated that the planting by machine in flate soil surprised the planting in furrow soil in all the mechanical criteria evaluation. Jamal et al., (2000) sown canola using four different sowing techniques included drill, broadcast, furrow and ridge with 4 replecation in random arrangement. The result showed that highest grain yield and yield compormls were recorded when seed were grown with ridge sowing. Grain yield in ridge sowing were higher by 45.31 and 28 $\%$ than broadcast, drill and furrow sowing methods respectively. Gamal et al. (2001) found that canola sowing by seed drill with a suitable raw width of $40 \mathrm{~cm}$ gave the highest yield and the lowest energy consumption compared with manual planting and planter. El Sayed et al. (2001) concluded that the highest yield of canola seeds $(1450 \mathrm{~kg} / \mathrm{fed})$ was obtained by using seed-drill with row spacing of $40 \mathrm{~cm}$, and the lowest yield $(682.84$ $\mathrm{kg} / \mathrm{fed}$ ) was obtained by using manual sowing with row spacing of $60 \mathrm{~cm}$. Gomaa (2003) compared the performance of two types of planters (pneumatic and mechanical) in cowpea planting. He found that the best seed germination, seed scratterig, planting depth and total yield were obtained under planting forward speed of $3.16 \mathrm{~km} / \mathrm{h}$. Also he said that the best results of planting uniformity and total yield were obtained with pneumatic planter compared to mechanical planter. Yehia et al. (2005) reported that the grain 
emergence percentage of cowpea using pneumatic planter was higher than using manual planting, seed drill and mechanical planter in flat and furrow soil. They added that the optimum grain emergence of $99.1 \%$ was obtained by using pneumatic planter in furrow and minimum of $62.44 \%$ was obtained by using manual planting in flat soil. Also they reported that the highest seed productivity $(1313 \mathrm{~kg} / \mathrm{fed})$ was obtained by using pneumatic planter in furrow soil.

So, the objectives of the present study are to investigate some manual and mechanical methods for canola planting and select optimum machine forward speed.

\section{MATERIALS AND METHOD}

The main experiments were carried out during the agricultural season 2012 / 2013 at Kafr El-Hamam research station, Sharkia Governorate.

\subsection{MATERIALS:}

2.1.1. The used crop: (canola crop -sarw 4 variety), Mass of 1000 seeds, (4 - $4.3 \mathrm{gm})$

\subsubsection{Sowing machines:}

- Mounted seed-drill (Gaspardo): 21 rows, spacing of $12 \mathrm{~cm}$ and seed rate of $2.3 \mathrm{~kg} / \mathrm{fed}$.

- Pneumatic planter (KOYMAK): 4 rows, spacing of $40 \mathrm{~cm}$ and working width $160 \mathrm{~cm}$. No. of cells on the disk of 40 cells, seed rate $1.5 \mathrm{~kg} / \mathrm{fed}$.

- Tractor Universal 650-M: of (75 Hp -55.93 kW) was used as a power source with all sowing implements.

\subsection{METHODS:}

The experimental area was about $2275 \mathrm{~m}^{2}$ divided into five similar plots ( $455 \mathrm{~m}^{2}$ each) to be sown by the different sowing methods.

\subsubsection{Experimental conditions:}

- Sowing methods: Five sowing methods were investigated (manual broadcasting - manual in ridge - manual transplanting- seed drill and pneumatic planter)

- Manual transplanting: After 30 days from sowing. No. of plant $/ \mathrm{m}^{2} 19$ plant row spacing of $60 \mathrm{~cm}$. investigated

- Manual in ridge: Row spacing of $60 \mathrm{~cm}$ with seed rate of $3.7 \mathrm{~kg}$.

The mechanical sowing methods were carried out under four different forward speeds of 2.2, 4.0, 5.3 and $6.3 \mathrm{~km} / \mathrm{h}$. 


\subsection{MEASUREMENT:}

2.3.1. Actual Field capacity: was the actual average time consumed during planting equation, (Keppner et al. 1982):

$$
\text { F. } C_{\text {act }}=\frac{60}{T u+T l}, \quad(\mathrm{fed} / \mathrm{h})
$$

Where: $F \cdot C_{\text {act }}=$ Actual field capacity.

$\mathrm{T}_{\mathrm{u}}=$ Utilization time per feddan in minutes.

$\mathrm{T}_{1}=$ Summation of lost time per feddan in minutes.

2.3.2. Field efficiency: is calculated by using the values of the theoretical field capacity and actual field capacity rates as, (Keppner et al. 1982):

$$
\eta_{\mathrm{f}}=\frac{\mathrm{F} \cdot \mathrm{C}_{\mathrm{act}}}{\mathrm{F} \cdot \mathrm{C}_{\mathrm{th}}} \times 100(\%)
$$

Where: $\eta_{\mathrm{f}}=$ Field efficiency.

2.3.3. Germination ratio: A sample of 100 seeds was germination and replicated three times before planting to investigate seed germination.

2.3.4. Plant emergency: was calculated by the following formula after three weeks from planting date.

$$
\text { Em. }=\frac{\mathrm{P}}{\mathrm{d}} \times 100, \quad(\%)
$$

Where: $\mathrm{P}=$ Average number of plants per $1 \mathrm{~m}^{2}$.

$\mathrm{d}=$ Average number of seeds delivered from metering device per $1 \mathrm{~m}^{2}$.

2.3.5. Plant characteristics: several plant characteristics were investigated during both flowering and harvesting stages such as:

- Average number of plant per $\mathrm{m}^{2}$ (population).

- Average plant height in $\mathrm{cm}$ measured from soil surface to the top of the main stem.

- Average number of seeds per plant.

- Average seed yield per plant.

2.3.6. Crop yield: Yield of canola was measured as follows:

- Average grain yield kg/fed.

- Average straw yield $\mathrm{kg} / \mathrm{fed}$.

- Average total yield $\mathrm{kg} / \mathrm{fed}$.

2.3.7. Energy consumed: To estimate the engine power during planting process, the decrease in fuel level accurately measuring immediately after 
each treatment. The following formula was used to estimate the engine power. (Hunt, 1983).

$$
\mathrm{EP}=\left[\mathrm{f} . \mathrm{c}(1 / 3600) \mathrm{PE} \times \mathrm{L} . \mathrm{C} . \mathrm{V} \times 427 \times \eta_{\mathrm{thb}} \times \eta_{\mathrm{m}} \times 1 / 75 \times 1 / 1.36\right], \mathrm{kW}
$$

Solving equation the consumed energy can be calculated as following:

$$
\text { Engine power }(\text { Diesel })=3.16 \text { f.c. }, \mathrm{kW}
$$

Where: f.c $=$ The fuel consumption, $(1 / h)$.

$\mathrm{PE}=$ The density of fuel, $(\mathrm{kg} / \mathrm{l})$, (for Diesel $=0.85)$.

L.C.V = The lower calorific value of fuel, $(11.000 \mathrm{k} . \mathrm{cal} / \mathrm{kg})$.

$\eta_{\text {thb }}=$ Thermal efficiency of the engine (35\% for Diesel).

$427=$ Thermo-mechanical equivalent, (kg.m/k.cal).

$\eta_{\mathrm{m}}=$ Mechanical efficiency of the engine ( $80 \%$ for Diesel).

Hence, the specific energy consumed can be calculated as follows:

$$
\text { Consumed energy }=\frac{\text { Engine power },(\mathrm{kW})}{\text { Actual field capacity },(\mathrm{fed} / \mathrm{h})}, \mathrm{kW} \cdot \mathrm{h} / \mathrm{fed}
$$

2.3.8. Planting cost: The total cost of planting operation was estimated using the following equation (Awady et al. 1982):

$$
\text { Operating cost }=\frac{\text { Machine cost }(\mathrm{L} . \mathrm{E} / \mathrm{h})}{\text { Actualfield capacity }(\mathrm{fed} / \mathrm{h})}, \mathrm{L} \cdot \mathrm{E} / \mathrm{fed}
$$

Machine cost was determined by using the following equation (Awady, 1978):

$$
\mathrm{C}=\frac{\mathrm{P}}{\mathrm{h}}\left(\frac{1}{\mathrm{a}}+\frac{\mathrm{i}}{2}+\mathrm{t}+\mathrm{r}\right)+(1.2 \mathrm{~W} \cdot \mathrm{S} \cdot \mathrm{F})+\frac{\mathrm{m}}{144}
$$

Where:

$\mathrm{C}=$ Hourly cost, L.E/h. $\quad \mathrm{P}=$ Price of machine, L.E.

$\mathrm{h}=$ Yearly working hours, $\mathrm{h} /$ year. $\mathrm{a}=$ Life expectancy of the machine, year.

$\mathrm{i}=$ Interest rate/year. $\quad \mathrm{F}=$ Fuel price, L.E/l.

$\mathrm{t}=$ Taxes, over heads ratio. $\quad \mathrm{r}=$ Repairs and maintenance ratio.

$\mathrm{m}=$ Monthly average wage, L.E $\quad 1.2=$ Factor accounting for lubrications.

$\mathrm{W}=$ Engine power, $\mathrm{hp} . \quad \mathrm{S}=$ Specific fuel consumption, $\mathrm{l} / \mathrm{hp} . \mathrm{h}$.

$144=$ Reasonable estimation of monthly working hours. 


\section{RESULTS AND DISCUSSION}

The obtained results will be discussed under the following items.

\subsection{Field capacity and field efficiency:}

Field capacity and field efficiency significantly varies from one planting method to another. Fig.1. show the effect of forward speed on both field capacity and field efficiency of the pneumatic planter and seed drill .Results obtained show a remarkable drop in the field efficiency with consequently sharp rise in field capacity as the forward speed increased. Increasing forward speed from 2.2 to $6.4 \mathrm{~km} / \mathrm{h}$ increased the field capacity from 0.84 to $2.4 \mathrm{fed} / \mathrm{h}$ and from 1.25 to $3.66 \mathrm{fed} / \mathrm{h}$. respectively. While decreased the field efficiency by 90.4 to $81.1 \%$ and from 88.1 to $69.4 \%$ respectively under the same previous conditions. The major reason for the reduction in field efficiency as the forward speed increased is due to the less theoretical time consumed in comparison with the other items of time losses. Results also show that the field capacity of manual broadcasting was $0.042 \mathrm{fed} / \mathrm{h}$ while their values were 0.025 and $0.032 \mathrm{fed} / \mathrm{h}$ under manual in ridge and manual transplanting respectively. Mean while field efficiency values were 69.20, 64.0 and $60.7 \%$ under the same previous conditions.

\section{3-2 Plant characteristics:}

Regarding to the emergence period, Fig.2. show that the complete emergence of plant was noticed after 8, 9, 5, and 6 days under seed drill, pneumatic planter, manual broadcasting, and manual in ridge respectively

This can be attributed to the fact that the depth of planting could not be adjusted under the mechanical planting methods. Considering the plant diameter, results in Fig.2 show that stem diameter values were 9.25, 10.2 and $20.6 \mathrm{~mm}$ under manual broad casting, manual in ridge and transplanting. While, under mechanical planting methods increasing forward speed from 2.2 to $6.4 \mathrm{~km} / \mathrm{h}$ increased stem diameter from 9 to 13 and 12 to $17 \mathrm{~mm}$ under seed drill and pneumatic planter, respectively.

Referring to the plant population, Fig.3. Increasing forward speed from 2.2 to $6.4 \mathrm{~km} / \mathrm{h}$, decreased plant population from 68 to 46 plant $/ \mathrm{m}^{2}$ for pneumatic planter, and from 143 to 110 plant/ $\mathrm{m}^{2}$ for seed drill respectively. Also Fig.3. show that the maximum stalk length of $177 \mathrm{~cm}$ was remarked under seed drill, while it decreased to 168, 145, 143, and 133 for manual broadcasting, manual in ridge, manual transplanting, and pneumatic planter respectively. 

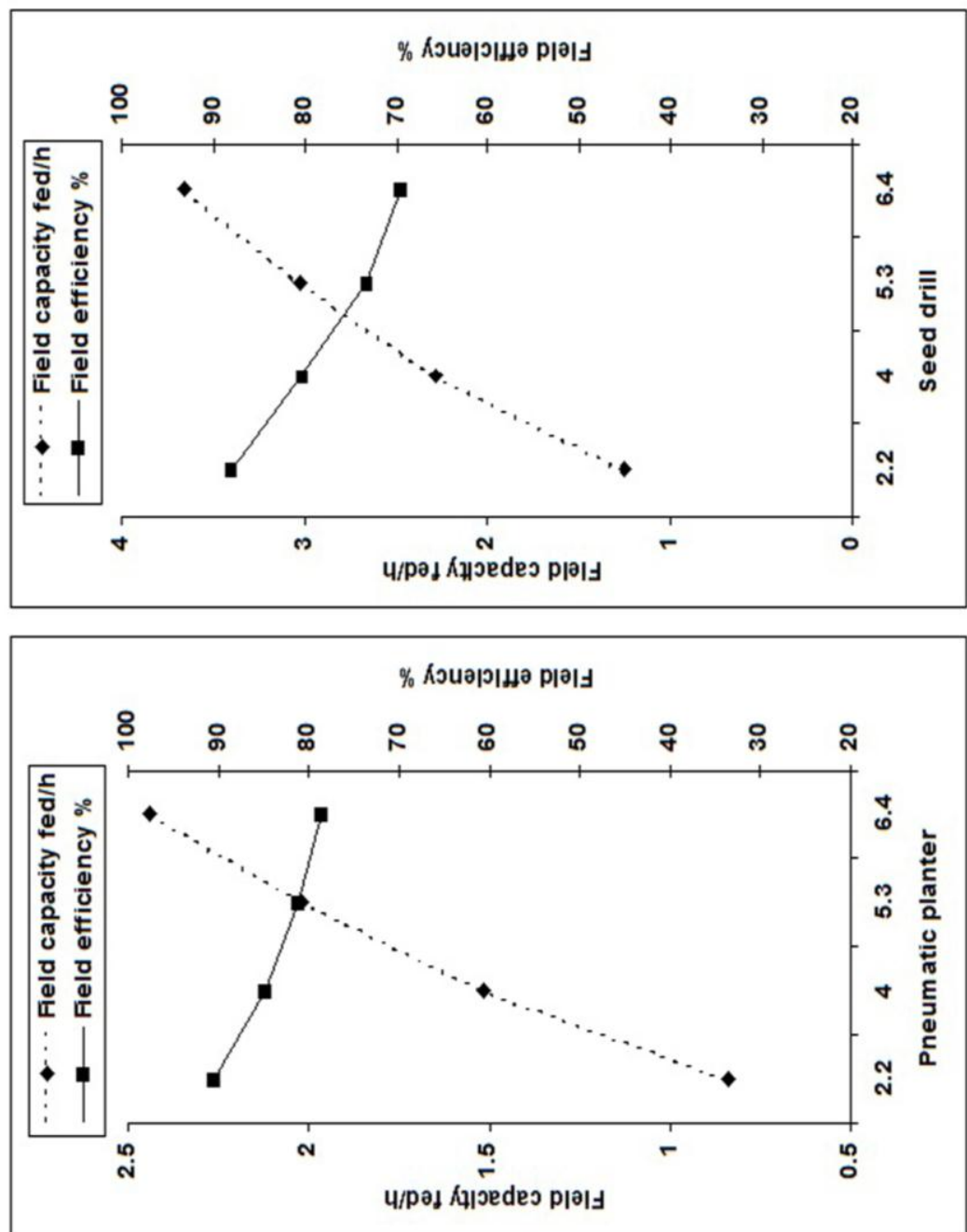

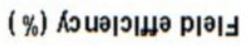

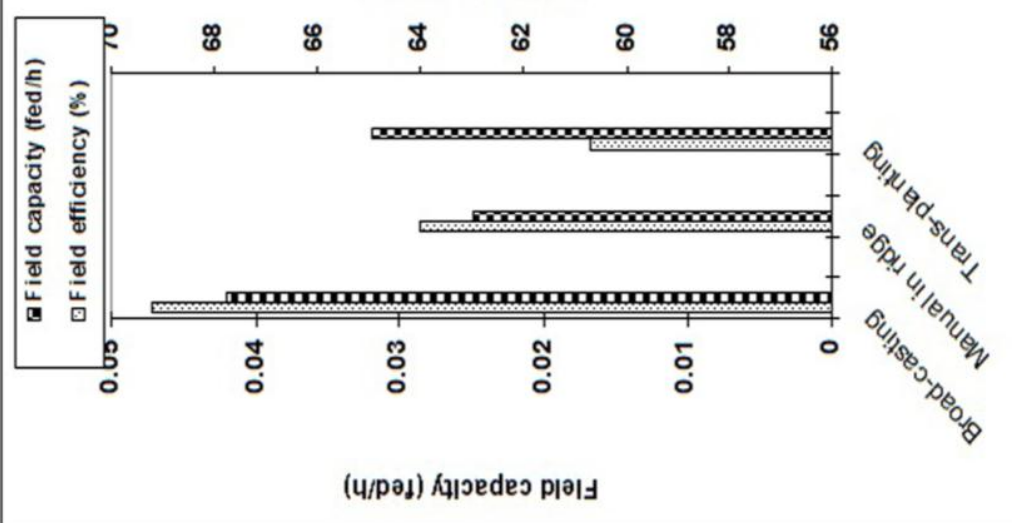

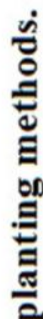

؛웅

을 

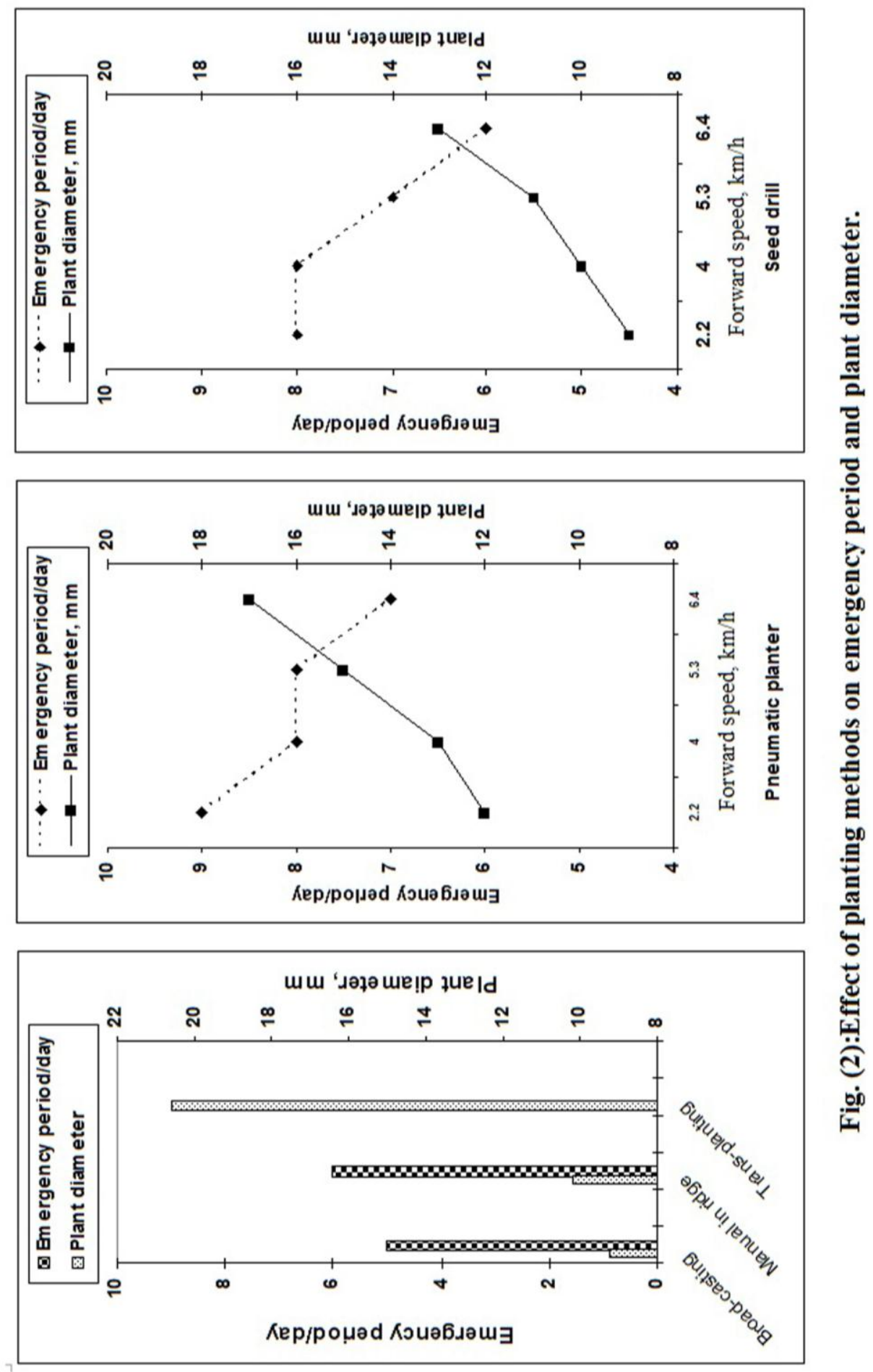


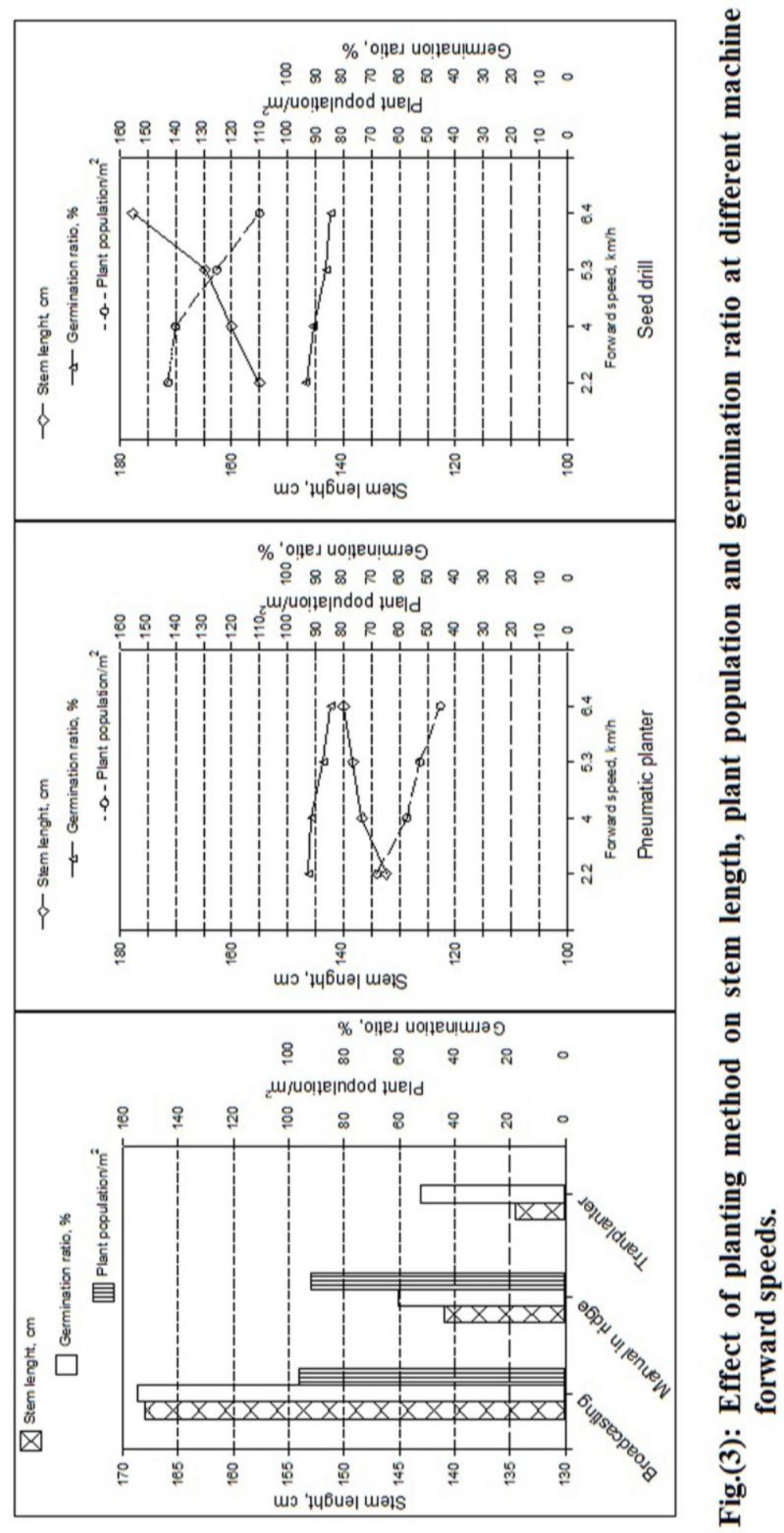


This can be attributed to the competition between adjacent plants under seed drill, which pushed them in the vertical direction to obtain enough light. Also to the effect of forward speed and planting method on germination ratio from results in Fig.(3) increasing forward speed from 2.2 to6.4km/h decreased germination ratio from 92.8 to $86.4 \%$ for pneumatic planter and from 93.2 to $85.7 \%$ for seed drill respectively.

While germination ratio values were 96.3, 92.1\% and - for manual broadcasting, manual in ridge and manual transplanting respectively.

\section{3-3 The yield and yield components of canola:}

Fig.4. show the effect of planting methods on canola yield under different forward speeds. Results showed that increasing forward speed from 2.2 to $6.4 \mathrm{~km} / \mathrm{h}$ decreased the seed yield of canola from 1580 to $1008 \mathrm{~kg} / \mathrm{fed}$ and from 1344 to $966 \mathrm{~kg} /$ fed under pneumatic planter and seed drill respectively. This attributed to the low plant number due to the low emergence ratio at high forward speeds. While the average values of manual planting methods (manual broadcasting, manual in ridge and manual transplant) were 924 1050 and $1093 \mathrm{~kg} / \mathrm{fed}$, respectively. Although the plant population was 152 , 43, and $19 \mathrm{plant} / \mathrm{m}^{2}$, manual broadcasting, manual in ridge, and manual transplant respectively. This is due to an increase in yield components of increased basal blanches and carrying the same number of fruiting branches on the main plant thus increase, the number of pods in the plant and thus increase the yield.

\section{3-4 Energy consumed:}

Fig.5. show the effect of different planting methods on the consumed energy under different forward speeds. Data indicate that, increasing forward speed from 2.2 to $6.4 \mathrm{~km} / \mathrm{h}$, increased power required from 18.23 to $26.54 \mathrm{~kW}$, and 18.86 to $27.33 \mathrm{~kW}$, under pneumatic planter and seed drill respectively. While the trend of energy consumed was against, since it were decreased from 21.7 to $10.87 \mathrm{~kW} . \mathrm{h} / \mathrm{fed}$ and 15.08 to $7.47 \mathrm{~kW} . \mathrm{h} / \mathrm{fed}$ under the same proviso conditions. This is attributed to the increase in field capacity.

Mean while energy values were 1.77, 2.98 and $2.32 \mathrm{kWh} /$ fed under manual broadcasting, manual in ridge and manual transplanting respectively. 

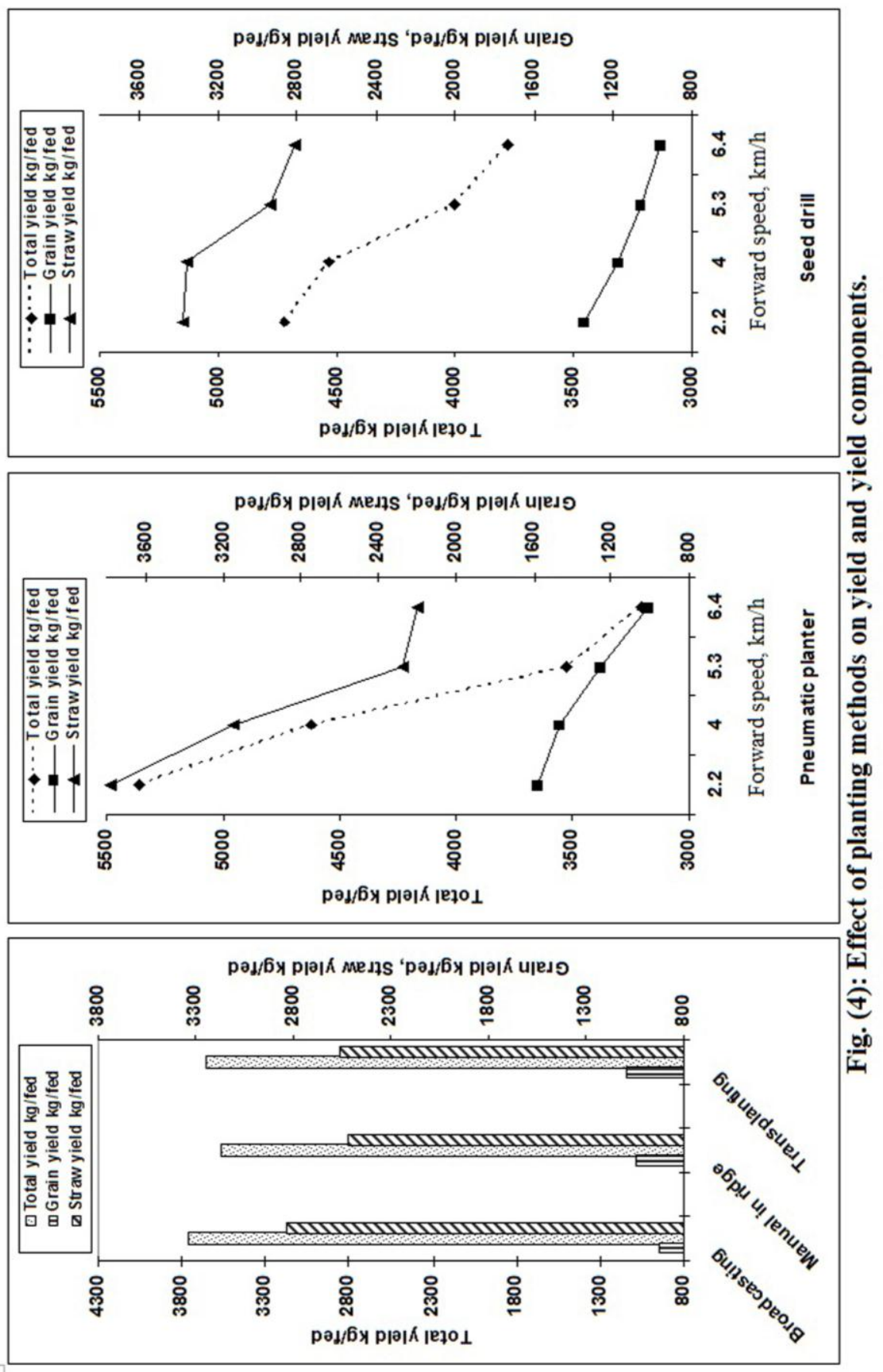


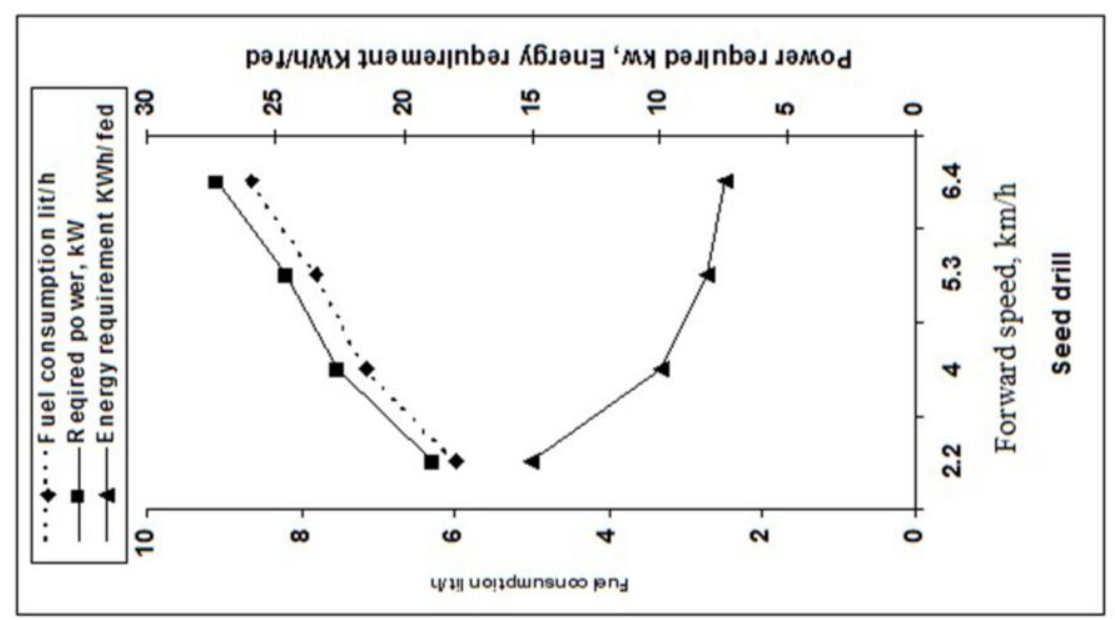

告

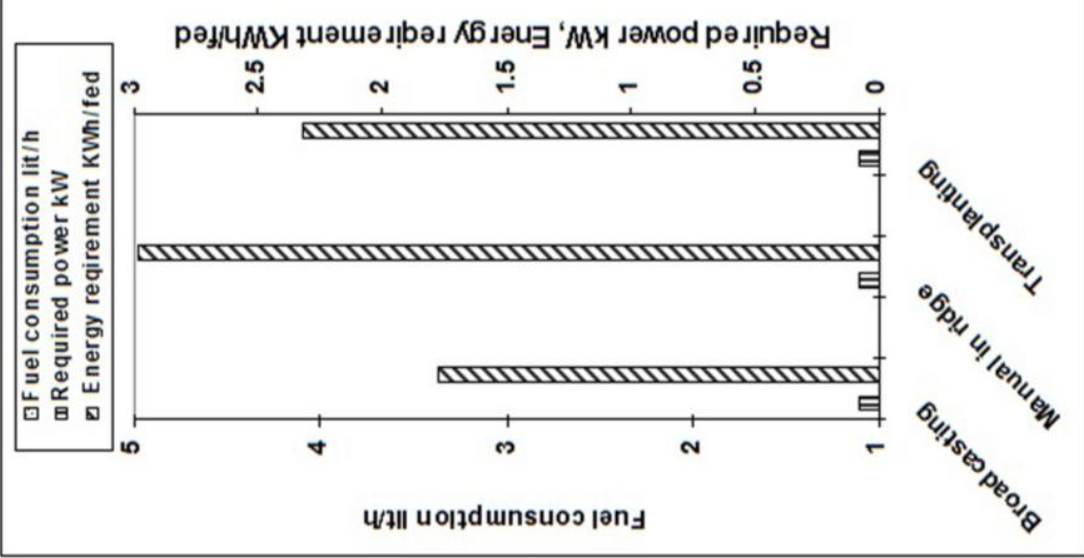




\section{3-5 The operational cost:}

The total cost of performing a field operation includes charges for the machine, the power utilized and labor. Machine cost includes deprecation, interest on investment, taxes, insurance, shelter, repairs and maintenance, lubrication and fuel. Fig.6. show the effect of forward speed on hourly and operational cost under planting methods. Results clarified that hourly cost increased by increasing forward speed, while vice versa was noticed with operational cost. Increasing forward speed, increased fuel consumption and hence increased hourly cost. The hourly cost values under different forward speeds of $2.2,4,5.3$, and $6.4 \mathrm{~km} / \mathrm{h}$ with the use of pneumatic planter and seed drill were 47.5, 48.3, 49.1, and 50.4L.E./h and 51.4, 52.7, 53.4, and $54.4 \mathrm{~L} . \mathrm{E} / \mathrm{h}$, respectively. Concerning the operational cost, it decreased by increasing forward speed. This may by due to the increase in field capacity when forward speed increased. While the average values of manual planting methods (manual broadcasting, manual in ridge and manual transplant) were 119.04, 194.50 and 300 L.E/fed, respectively.

\section{CONCLUSION}

From the obtained data it could be concluded the followings:

- The maximum canola yield of $1580 \mathrm{~kg} / \mathrm{fed}$ was recorded with the use of pneumatic planter under forward speed of $2.2 \mathrm{~km} / \mathrm{h}$,

- The minimum power required and maximum energy consumed of $18.23 \mathrm{~kW}$ and $21.7 \mathrm{~kW} . \mathrm{h} / \mathrm{fed}$ were recorded at pneumatic planter forward speed of 2.2 $\mathrm{km} / \mathrm{h}$.

- The minimum planting cost of 14.8 L.E/fed was recorded with the use of seed drill at forward speed of $6.4 \mathrm{~km} / \mathrm{h}$. compared with manual planting which recorded 300.194 .5 and 119.04 L.E/fed, for manual transplanting, manual in ridge and manual broadcasting respectively.

\section{REFERENCES}

Abdou, F. M; (1995): Effect of seed-bed preparation and plant population on onion crop production, The Role of Ag. Eng. IN Sustainable Development $3^{\text {rd }}$ Conf. of Misr Society of Ag.Eng, 5-6 October 1995: 153 - 162

Awady, M. N. (1978): Tractor and farm machinery. Text book, Faculty of Agriculture, Ain-Shams University. Pp: 164-167. 

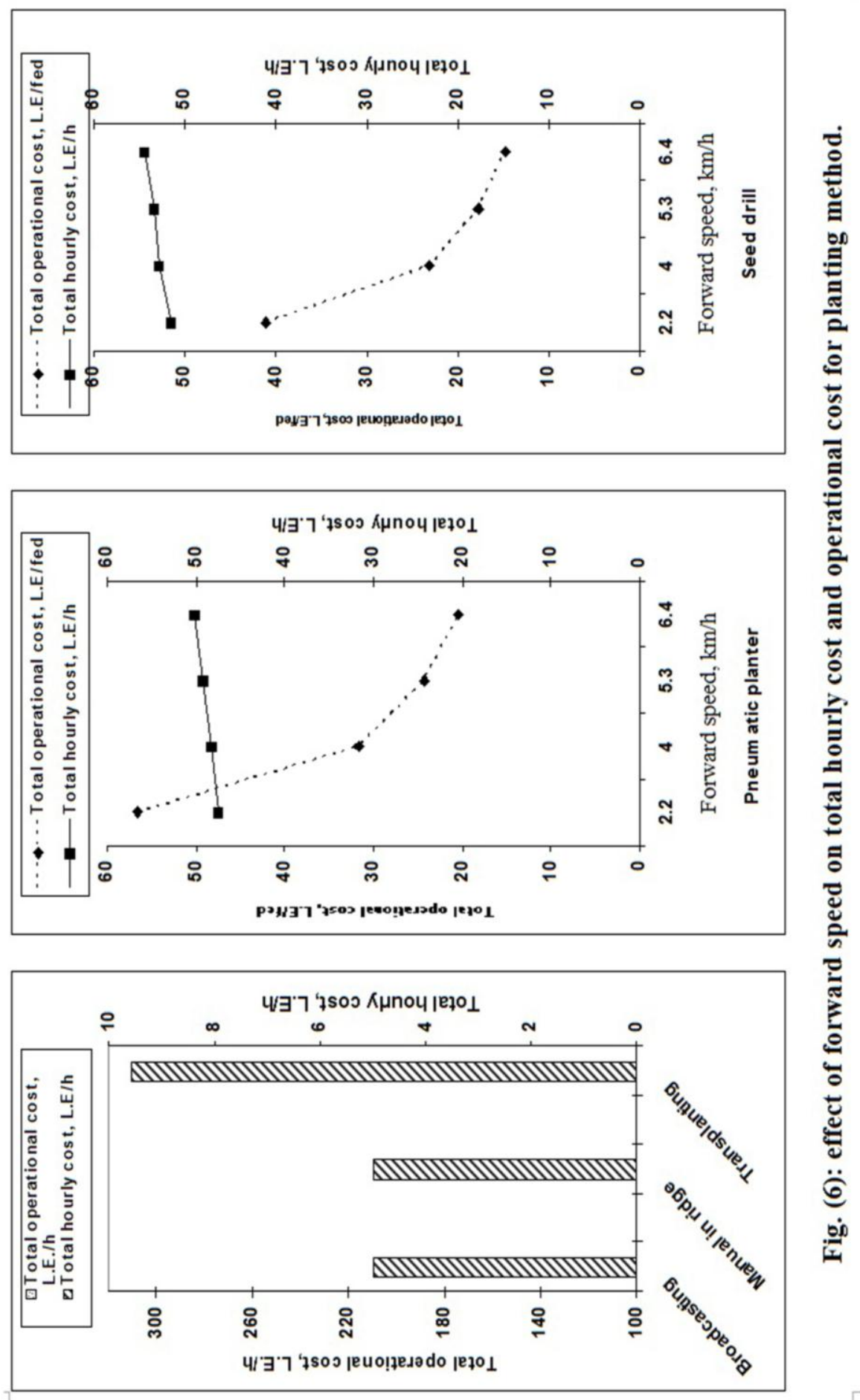
Awady, M. N; E. Y. Ghoneim and A. I. Hashish (1982): A critical comparison between wheat combine harvester under Egyptian conditions. R. S. No. 1920, Ain-Shams University. (FAO) J.

El-Sayed, G.H; M.A., El- Attar, S. E. ,Badr, and I.,Yehia, 2001.Effect of some mechanical planting systemes on canola crop yield, $9^{\text {th }}$ Conf of Misr Soc. of Ag. 10- 12 December, under Publishing .

El-Shal, M. S.(1987):A study on usability of pneumatic planter under Egyption .

Gamal, H. E., M. A. El-Attar., S. E. Bader and I. Yahia (2001). Effect of mechanical planting system on Canola crop yield. Misr J. Agric. Eng., 18 (4): 163-172 .

Gomaa, S.M.(2003):Performance evaluation of pneumatic and mechanical planters for cowpea planting. Misr J.Ag.Eng.,20 (4):965 - 979

Hunt, D. (1983): Farm power and machinery management. $8^{\text {th }}$ Ed. Iowa state Univ., Press Ames, USA. Ames, Iowa, USA: 364-368

Imbabi, A. T., (1996) :Effect of field dimension on the performance and productivity of the planter machine for planting sun flower seeds in flat and furrow soil. . Misr J.Ag.Eng.13 (3) july.

Jamal M. khan, Rian A. Khattak and M. Asim Khan (2000): Influence of sowing methods on the productivity of canola grown in saline field. Pakistan Journal of biological. 3 (4) : 687-691 .

Kepner, R. A; K. Bainer and E. L. Barger (1982): Principles of farm machinery. $3^{\text {rd }}$ Ed., AVI Pub. Com. Inc., Westport. 527pp.

Moustafa, E.M.(1993): Mechanization of soybean crop. M. Sc. Thesis, fac. Ag. Zagazig Univ.

Sharma, D.N., Bansal, N.K., and Jain, M. I., (1983): Design, development and testing of bullock-drawn, row seed-cum fertilizer drill, A M A 14(2): 37 - 40.

Srrivastava, A.C,(1993): Elements of farm machinery. Oxford and IBH publishing Co. New Delhi.

Yehia, I.,S.E. Bader; and A. Lotfy (2005):Effect of some planting systems on cowpea crop productivity. The $13^{\text {th }}$ conference of the Misr society of Ag. Eng. 14-15 December. 670- 678 . 


\section{الملخص العربى}

\section{اختيار الطريقة المثلى لزراعة محصول الكانولا

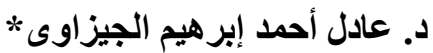

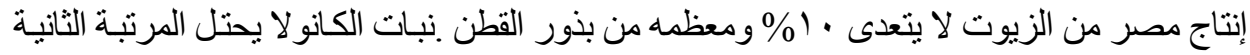

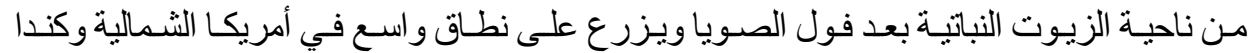

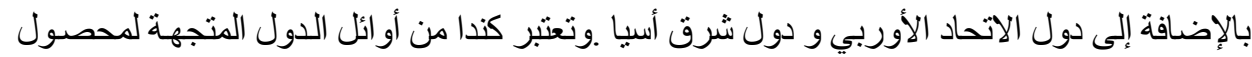

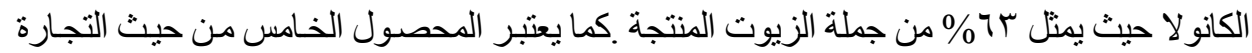

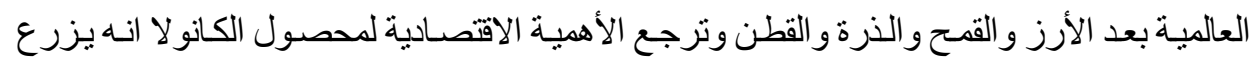

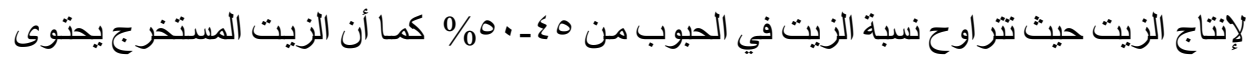
على ؟9\% أحمـاض دهنية غير مشبعة و 7\% فقط أحماض مشبعة .و الكسب الناتج كعلف للحيوان

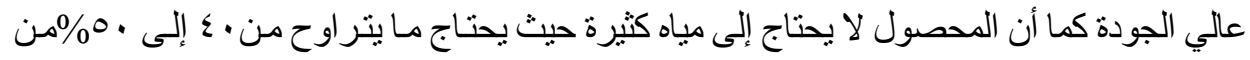

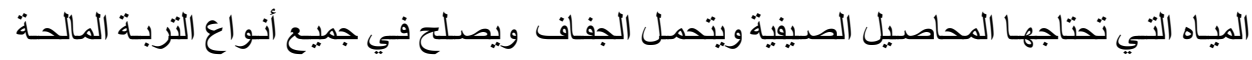

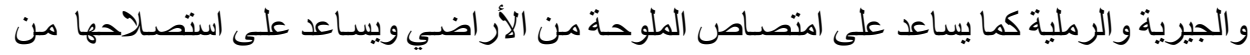

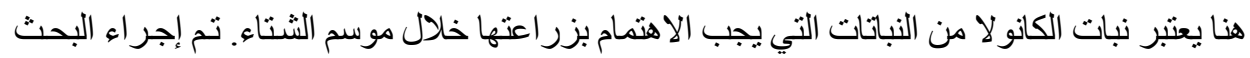

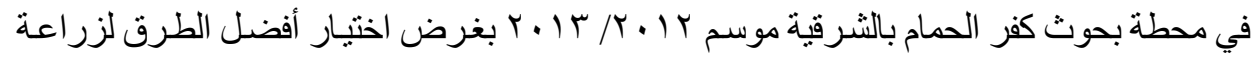

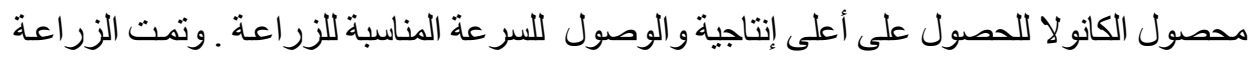

بطريقتين: مبون

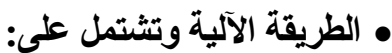

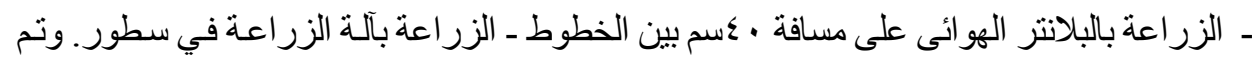

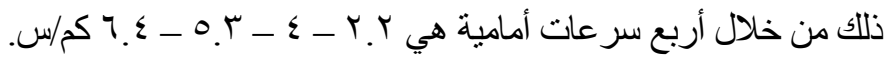

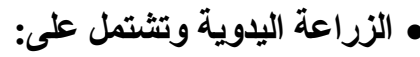

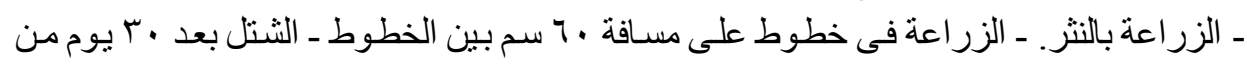

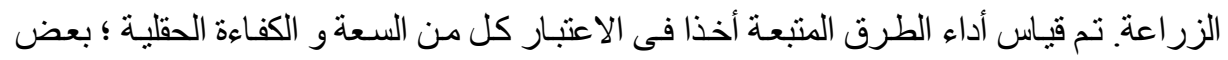
المو اصفات النباتية ؛ إنتاجية المحصول ؛ الطاقة المستهلكة و تكاليف التشغيل.

\section{وقد أظهرث النتائج المتحصل عليها على ما يلي:}

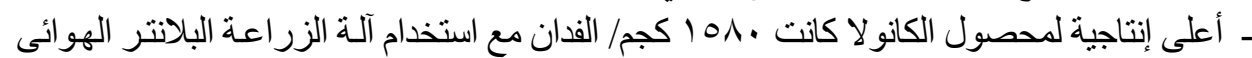

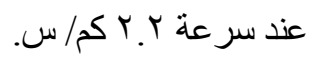

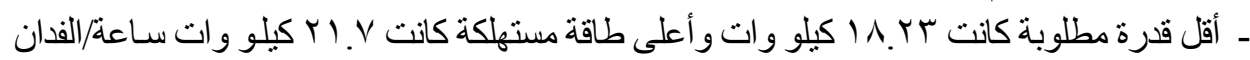

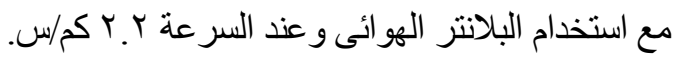

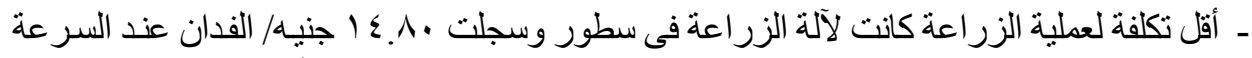

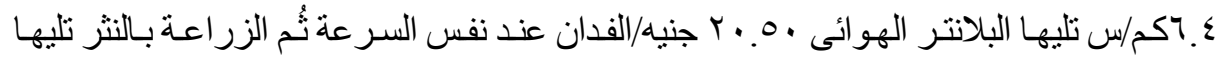

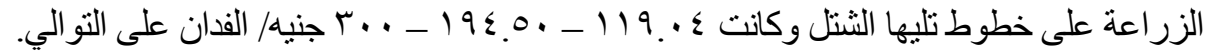

باحث - معهد بحوث الهندسة الزراعية ـ مركز البحوث الزراعية - مصر. 